\title{
Neuronal-Glial Interactions Mediated by Interleukin-1 Enhance Neuronal Acetylcholinesterase Activity and mRNA Expression
}

\author{
Yuekui Li, ${ }^{1}$ Ling Liu, ${ }^{1}$ Jinsong Kang, ${ }^{1,9}$ Jin G. Sheng, ${ }^{1}$ Steven W. Barger, ${ }^{1,2,6}$ Robert E. Mrak, ${ }^{2,3,8}$ and \\ W. Sue T. Griffin ${ }^{1,2,4,5,6,7}$ \\ ${ }^{1}$ Donald W. Reynolds Department of Geriatrics and the Departments of ${ }^{2}$ Anatomy, ${ }^{3}$ Pathology, ${ }^{4}$ Medicine, and \\ ${ }^{5}$ Psychiatry, University of Arkansas for Medical Sciences, Little Rock, Arkansas 72205, 6the Geriatric Research, \\ Education, Clinical Center, ${ }^{7}$ Mental IIIness Research Education and Clinical Center, and ${ }^{8}$ Pathology Service, McClellan \\ Memorial Veterans Affairs Medical Center, Little Rock, Arkansas 72205, and ${ }^{9}$ Department of Pathophysiology, Norman \\ Bethune University of Medical Sciences, Changchun 130021, People's Republic of China
}

Cholinergic dysfunction in Alzheimer's disease has been attributed to stress-induced increases in acetylcholinesterase (AChE) activity. Interleukin-1 (IL-1) is overexpressed in Alzheimer's disease, and stress-related changes in long-term potentiation, an ACh-related cerebral function, are triggered by interleukin-1. Microglial cultures (N9) synthesized and released $\mathrm{IL}-1$ in response to conditioned media obtained from glutamate-treated primary neuron cultures or PC12 cells. This conditioned media contained elevated levels of secreted $\beta$-amyloid precursor protein (SAPP). Naive PC12 cells cocultured with stimulated N9 cultures showed increased AChE activity and mRNA expression. These effects on AChE expression and activity could be blocked by either preincubating the glutamate-treated PC12 supernatants with anti-sAPP antibodies or preincubating naive $\mathrm{PC} 12$ cells with IL-1 receptor antagonist. These findings were confirmed in vivo; IL-1-containing pellets implanted into rat cortex also increased AChE mRNA levels. Neuronal stress in Alzheimer's disease may induce increases in AChE expression and activity through a molecular cascade that is mediated by SAPP-induced microglial activation and consequent overexpression of IL-1.

Key words: acetylcholinesterase; Alzheimer's disease; $\beta$-amyloid precursor protein; choline acetyltransferase; cholinergic systems; interleukin-1; neuronal cultures; neuronal stress; PC12 cells
Cholinergic dysfunction in Alzheimer's disease has long been recognized (Whitehouse et al., 1981; Bartus et al., 1982). The early memory deficits characteristic of Alzheimer's disease have been attributed, in part, to cholinergic hypof unction, with hyperactivity of acetylcholinesterase (AChE), a postsynaptic enzyme that terminates cholinergic synaptic transmission through hydrolysis of acetylcholine (Hall and Kelly, 1971) and is prominent and overexpressed by neurites associated with $\beta$-amyloid plaques in Alzheimer brain (Mesulam, 1986; Moran et al., 1993; Alvarez et al., 1997). AChE, in turn, has been shown to regulate processing of the $\beta$-amyloid precursor protein ( $\beta$ APP) (Mori et al., 1995) and to accelerate assembly of amyloid peptide into $\beta$-amyloid fibrils in vitro (Inestrosa et al., 1996), suggesting a link between $\mathrm{AChE}$ overexpression and $\beta$-amyloid formation. Overexpression of human AChE in neurons of transgenic mice produces progressive cognitive deterioration as assessed by the Morris water maze (Beeri et al., 1995), suggesting that downregulation of cholinergic function is detrimental to spatial memory (Winkler et al., 1995). AChE may also play a role in cellular development and neuronal

Received July 20, 1999; revised Oct. 13, 1999; accepted Oct. 18, 1999.

This work was supported in part by National Institutes of Health Grant AG12411 and the Donald W. Reynolds Foundation (W.S.T.G.), and National Institutes of Health Grant NS35872, the Alzheimer's Association, and the Inglewood Foundation (S.W.B.). We gratefully acknowledge the technical assistance of Richard Jones and the secretarial assistance of Pam Free.

Correspondence should be addressed to Prof. Sue Griffin, Research Services 151/LR, 4300 West Seventh Street, Little Rock, AR 72205. E-mail: griffinsuet@exchange.uams.edu.

Copyright (C) 1999 Society for Neuroscience 0270-6474/99/200149-07\$15.00/0 growth, unrelated to its classic acetylcholine-hydrolyzing activity (Layer and Willbold, 1995; Sternfeld et al., 1998).

The mechanism underlying altered expression of AChE in Alzheimer's disease remains unclear (Younkin et al., 1986). Acute stress is known to induce expression of the AChE gene and to increase brain AChE activity (Kaufer et al., 1998). Overexpression of the $\mathrm{C}$-terminal fragment of human $\beta \mathrm{APP}$ in brain of transgenic mice also results in increased tissue levels of $\mathrm{AChE}$ (Sberna et al., 1998), suggesting feedback effects between AChE and $\beta$ APP expression.

Interleukin-1 (IL-1) is a microglia-derived cytokine with potent modulatory effects on neurons (Griffin et al., 1989) that is overexpressed in brain of patients with Alzheimer's disease. IL-1 has an important neuromodulatory role in hippocampus (Schneider et al., 1998) and may be a common trigger for age- and stress-induced impairments in long-term potentiation there (Murray and Lynch, 1998a). An interleukin-1-driven cytokine cycle of molecular and cellular events, and interactions has been proposed as a basic pathophysiological mechanism underlying the progression of Alzheimer pathology (Griffin et al., 1998), including conversion of diff use amyloid deposits into diagnostic neuritic $\beta$-amyloid plaques (Griffin et al., 1995). A trophic effect of IL-1 on AChE expression might explain the overexpression of $\mathrm{AChE}$ in the dystrophic neurites of these $\beta$-amyloid plaques. In this study, we sought to identify possible effects of IL-1 on AChE activity and/or expression in vitro using primary neuronal cell cultures and PC12 cells, as well as in vivo using a pellet implantation paradigm in rat brain. We also explored the ability of glutamate-mediated stress to initiate such cascades through the 
indirect induction of IL-1 in neuron-glia cocultures. We found that microglial overexpression of IL-1 could be induced by secreted $\beta$-amyloid precursor protein (sAPP) released from glutamate-treated PC12 cells. This IL-1, in turn, promoted neuronal expression and activity of AChE. In contrast, levels of the acetylcholine-synthesizing enzyme choline acetyltransferase (ChAT) were unaffected by these treatments.

\section{MATERIALS AND METHODS}

Pellet implantation. Pellets impregnated with IL-1 $\beta$ [100 ng of recombinant mouse IL-1 $\beta$ (Sigma, St. Louis, MO)] and "control" pellets (without IL-1 $\beta$ impregnation) were obtained from Innovative Research of America (Sarasota, FL). These pellets were $1.5 \mathrm{~mm}$ in diameter and designed for controlled, slow release of IL-1 over a $21 \mathrm{~d}$ period. Such pellets have been used for many studies, including those designed for slow-release delivery of IL-2 (Paciotti and Tamarkin, 1988).

Twenty-one male Sprague Dawley rats, weighing $264 \pm 6 \mathrm{gm}$, were randomly assigned to three groups. Eight rats received implants of IL-1-containing pellets, seven rats received pellets without interleukin-1 impregnation, and six rats served as unoperated controls. The rats were maintained under conventional conditions at $25^{\circ} \mathrm{C}$ and fed a commercial diet and tap water, and on the $21 \mathrm{st} \mathrm{d}$ after implantation, cortex from the left hemisphere was collected for RNA isolation.

For pellet implantation, rats were anesthetized with ketamine and xylazine and placed in a stereotaxic frame. The pellets were implanted $2.8 \mathrm{~mm}$ caudal to bregma, $4.5 \mathrm{~mm}$ right of the midline, and $2.5 \mathrm{~mm}$ deep to the pial surface.

Cell culture. Primary neuronal cultures were derived from cerebral cortex, hippocampus, and basal forebrain of fetal (embryonic day 18), and from cerebellum (10 d postnatal) of Sprague Dawley rats, as described previously (Li et al., 1998). Experiments using primary neuronal cell cultures were performed after $10-14 \mathrm{~d}$ in culture. Cell survival was assessed, as described previously (Li et al., 1998), using the 3-[4-5dimethythiazol-2-yl]-2,5-diphenyl-tetrazolium bromide (MTT) assay.

A cultured pheochromocytoma cell line (PC12 cells; American Type Culture Collection, Rockville, MD) was maintained in 5\% fetal bovine serum (FBS) (Amersham, Arlington Heights, IL) and 10\% horse serum in RPMI 1640 medium (Life Technologies, Gaithersburg, MD). To induce neuronal differentiation, PC12 cells were plated onto culture dishes precoated with rat tail collagen type I (Sigma) and maintained in $1 \%$ horse serum RPMI medium containing $50 \mathrm{ng} / \mathrm{ml}$ mouse $2.5 \mathrm{~S}$ nerve growth factor (Sigma) with half of the medium changed every $3 \mathrm{~d}$. Growth of cell processes was readily evident by day 10 in culture, at which time the PC12 cell cultures were used for experiments. The N9 mouse microglial cell line (Corridan et al., 1993) were maintained as described previously (Barger and Harmon, 1997).

Cell treatments. To determine whether IL-1 directly regulates the activity and synthesis of AChE, both primary neuronal cultures and PC12 cell cultures were treated with mouse IL-1 $\beta$ (Sigma), 10 or 100 $\mathrm{ng} / \mathrm{ml}$, with or without mouse IL-1 receptor antagonist (IL-1ra) (R \& D Systems, Minneapolis, MN), 100 or $500 \mathrm{ng} / \mathrm{ml}$. To examine diffusible signals elicited by metabolic and oxidative neuronal stress, conditioned medium was collected from two neuronal culture models. PC12 cells or primary cortical neurons were exposed to $500 \mu \mathrm{M}$ glutamate in DMEM for $15 \mathrm{~min}$, then washed twice with DMEM (for $35 \mathrm{~mm}$ dishes, $2 \mathrm{ml}$ DMEM each time), and further incubated in serum-free medium (1.5 $\mathrm{ml})$ for $2 \mathrm{hr}$. Then, the culture medium was centrif uged $(12,000 \times g$ for $5 \mathrm{~min}$ ), and the supernatant was stored at $-70^{\circ} \mathrm{C}$ until used.

For microglia-neuronal cell coculture, PC12 cells were seeded in 25 $\mathrm{mm}$ culture inserts (pore size of $0.4 \mu \mathrm{m}$ ) (Nunc, Naperville, IL) precoated with poly-D-lysine, and N9 cells were seeded in $35 \mathrm{~mm}$ dishes. The N9 cell cultures were pretreated for $12 \mathrm{hr}$ with untreated medium, glutamate-treated conditioned medium, or conditioned medium preabsorbed with anti- $\beta$ APP antibodies (Alzheimer 90, clone 1.D5; Boehringer Mannheim, Indianapolis, IN). Then, naive PC12 cell cultures grown on the permeable $(0.4 \mu \mathrm{m})$ membranes of basket inserts were cocultured with N9 cells. After coculture, the PC12 cells were harvested for assay of AChE and ChAT activity. In some experiments, coculture of PC12 cell cultures and N9 cell cultures was performed in the presence of IL-1ra (100-500 ng/ml).

Assay of AChE and ChAT activity. Cell cultures, in culture dishes or in coculture inserts, were washed twice with cold PBS, $\mathrm{pH} 7.4$, scraped into a $1 \mathrm{ml}$ volume of $50 \mathrm{~mm}$ sodium phosphate buffer, $\mathrm{pH}$ 7.4, and transferred to centrif uge tubes. The cell pellet obtained by centrifugation $(12,000 \times$ $g$ for $3 \mathrm{~min}$ ) was resuspended in $50-100 \mu \mathrm{l}$ of PBS and sonicated. Protein concentration was determined using a Micro BCA protein assay reagent kit (Pierce, Rockford, IL).

AChE activity was determined using a modification of a previously reported method (Ellman et al., 1961). Briefly, $50 \mu \mathrm{g}$ of sample was added to a reaction mix ( $1 \mathrm{ml}$ total volume) containing $0.1 \mathrm{M}$ Tris- $\mathrm{HCl}$ buffer, pH 7.2, $0.75 \mathrm{~mm}$ acetylthiocholine iodide (Sigma) as substrate, 0.3 $\mathrm{mm} 5,5^{\prime}$-dithio(bis)nitrobenzoic acid, and $0.1 \mathrm{~mm}$ tetraisopropyl pyrophosphoramide (Sigma) as an inhibitor of nonspecific cholinesterases. Butyrylcholinesterase (BuChE) activity was measured under similar conditions using $5 \mathrm{~mm}$ butyrylcholine iodide as substrate and $10 \mu \mathrm{M}$ BW284c51 dibromide (Sigma) to inhibit AChE. The reactions were stopped by lowering the temperature of assay mixtures to $0^{\circ} \mathrm{C}$.

ChAT activity was determined using the radioenzymatic assay of Fonnum (1975). Briefly, 100-200 $\mu \mathrm{g}$ samples were diluted to an appropriate volume with PBS. Samples were incubated for $30 \mathrm{~min}$ at $37^{\circ} \mathrm{C}$ after addition of $200 \mu \mathrm{l}$ of PBS containing: $150 \mathrm{~mm} \mathrm{NaCl}, 5 \mathrm{~mm}$ EDTA, $5 \mathrm{~mm}$ choline, $0.1 \mathrm{~mm}$ esterine, and $0.25 \mu \mathrm{Ci}$ of $\left[{ }^{3} \mathrm{H}\right.$ ] acetyl-CoA (ICN, Costa Mesa, CA). The reaction was terminated by the addition of $200 \mu \mathrm{l}$ of $1.5 \%$ tetraphenylboron in 3-heptanone (Sigma), and the mixtures were vortexed. Samples $(75 \mu l)$ of the resultant upper phase (containing $\left[{ }^{3} \mathrm{H}\right]$ acetylcholine) were added to $5 \mathrm{ml}$ of ScintiVerse II (as a scintillator), and the radioactivity was determined using a Packard (Downers Grove, IL) 2500 TR Liquid Scintillation Analyzer.

AChE histochemistry. AChE histochemistry was performed, with minor modifications, as described by Tago et al. (1986). Cultures were fixed with $4 \%$ paraformaldehyde for $30 \mathrm{~min}$, after which they were rinsed three times with PBS. The cultures were then incubated in a fresh solution consisting of $3 \mathrm{~mm}$ copper sulfate, $5 \mathrm{~mm}$ sodium citrate, $0.5 \mathrm{~mm}$ potassium ferricyanide, and $1.8 \mathrm{~mm}$ acetylthiocholine iodide in $0.1 \mathrm{~mm}$ malate buffer, $\mathrm{pH} 6.0$, for $1 \mathrm{hr}$ in $37^{\circ} \mathrm{C}$. After two rinses with $0.5 \mathrm{~mm}$ Tris- $\mathrm{HCl}$, $\mathrm{pH} 7.6$, the cultures were incubated in an intensification solution $(0.04 \%$ $\mathrm{DAB}$ and $0.003 \% \mathrm{H}_{2} \mathrm{O}_{2}$ in Tris- $\mathrm{HCl}$ buffer) for $20 \mathrm{~min}$. To determine the percent of histochemically labeled cells in the different paradigms, cultures were photographed, images were digitized, and then labeled cells were counted in 20 fields each of triplicate cultures.

$R N A$ isolation. Total RNA was extracted from cultured cells or from brain tissue, using TriReagent RNA (Molecular Research Center, Inc., Cincinnati, $\mathrm{OH}$ ) according to the manufacturer's instructions. Integrity of isolated RNA was verified on agarose gels with ethidium bromide staining, and quantification of isolated RNA was performed using spectrophotometric absorbance at $260 \mathrm{~nm}$. RNA samples used in this study had 260:280 ratios of 1.7-2.0.

Reverse transcription reaction and PCR amplification. Reverse transcription (RT) of $3 \mu \mathrm{g}$ samples of extracted total RNA was performed using an Advantage RT-for-PCR kit (Clontech, Palo Alto, CA) according to the manufacturer's instructions. For comparisons of mRNA levels among different RNA samples, RT was performed simultaneously using reagents from a single master mix.

PCR amplification was performed using reagents from Clontech. For mouse IL-1 $\beta$, the forward primer was 5' ATG GCA ACT GTT CCT GAA CTC AAC T 3', creating a 540 bp amplimer, and the reverse primer was 5' AGG ACA GGT ATA GAT TCT TTC CTT T 3', creating a 540 bp amplimer. For rat AChE, the forward primer was 5' TCT TTG CTC AGC GAC TTA 3', and the reverse primer was 5' GTC ACA GGT CTG AGC ATC T 3', yielding an amplified product of $340 \mathrm{bp}$. For glyceraldehyde-3-phosphate dehydrogenase (G3PDH) amplification, the forward primer was 5' ACC ACA GTC CAT GCC ATC AC 3', and the reverse primer was 5' TCC ACC ACC CTG TTG CTG TA 3', creating a $452 \mathrm{bp}$ amplimer. For PCR, the $1 \mu \mathrm{l}$ RT product of each sample was placed in a final $50 \mu \mathrm{l}$ reaction mixture containing each of the above forward and reverse primers ( $0.4 \mu \mathrm{M}$ each), $5 \mu \mathrm{l}$ of $10 \times$ PCR buffer, 0.2 mM dNTP, and 2.0 units of Taq polymerase. For IL- $1 \beta$, amplification was performed through 22 cycles at $94^{\circ} \mathrm{C}$ for $45 \mathrm{sec}, 60^{\circ} \mathrm{C}$ for $45 \mathrm{sec}$, and $72^{\circ} \mathrm{C}$ for $45 \mathrm{sec}$. For AChE or G3PDH, amplification was performed through 30 cycles at $94^{\circ} \mathrm{C}$ for $45 \mathrm{sec}, 55^{\circ} \mathrm{C}$ for $45 \mathrm{sec}$, and $72^{\circ} \mathrm{C}$ for $45 \mathrm{sec}$. The PCR reaction was stopped by final extension for $10 \mathrm{~min}$ at $72^{\circ} \mathrm{C}$. Equal volumes of reaction mixture from each sample were loaded onto $1.5 \%$ agarose gels, and fluorescent images were digitally captured for analysis. Levels of IL- $1 \beta$ mRNA and AChE mRNA were normalized relative to signal from corresponding G3PDH mRNA bands using NIH Image 1.6 software.

Radioimmunoprecipitation. To radiolabel $\beta$ APP in cell lysates of and sAPP in media from glutamate-treated PC12 cells, and IL- $1 \beta$ in media from "activated" N9 cells, cultures were serum-starved for $20 \mathrm{~min}$ in 


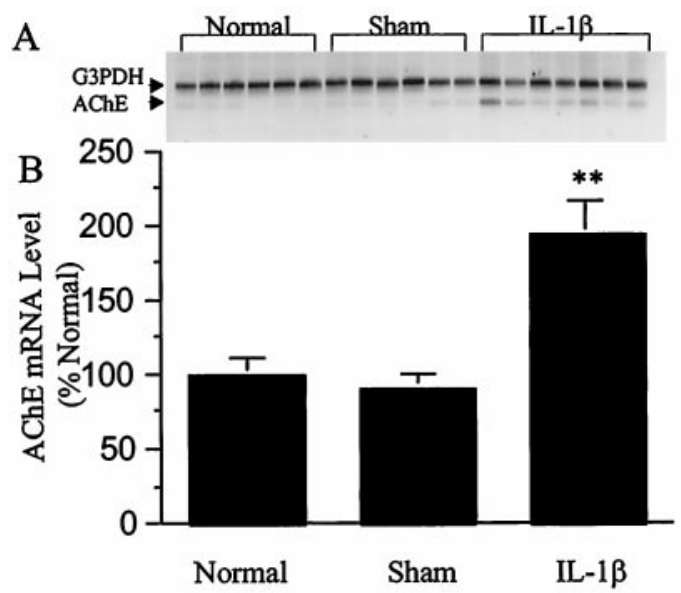

Figure 1. IL-1 $\beta$ induction of AChE mRNA in vivo. Illustration $(A)$ and quantification $(B)$ of $\mathrm{AChE}$ and G3PDH mRNA levels in cortex of rats after $21 \mathrm{~d}$ exposure to slow-release pellets containing IL- $1 \beta$ or vehicle (sham) or unoperated normal rat. Values are expressed as mean \pm SEM. $*^{*} p<0.01$, significantly different from control.

DMEM methionine-free medium and then incubated with $200 \mu \mathrm{Ci} / \mathrm{ml}$ $\left[{ }^{35}\right.$ S $]$ methionine in DMEM, containing $1 \%$ FBS $(>1000 \mathrm{Ci} / \mathrm{mmol})$ for 3 hr. Radiolabeled translation products were then immunoprecipitated as described previously (Barger and Mattson, 1996). Briefly, the supernatants and cell lysates were precleared with protein G-agarose (Boehringer Mannheim) and then incubated overnight at $4^{\circ} \mathrm{C}$ with hamster anti-murine IL- $1 \beta$ monoclonal antibody $(5-10 \mu \mathrm{g} / \mathrm{ml}$; Genzyme, Boston, MA) or with mouse monoclonal anti-Alzheimer $90(10 \mu \mathrm{g} / \mathrm{ml}$; Boehringer Mannheim), followed by a $4 \mathrm{hr}$ precipitation with $20 \mu \mathrm{l}$ of protein $\mathrm{G}$-agarose per $1 \mathrm{ml}$ of sample. Immunoprecipitates were analyzed on $12 \%$ (for IL-1 $\beta$ ) or $8 \%$ (for APPs) SDS-PAGE gels. The gels were fixed and equilibrated in an Amplify autoradiography enhancer (Amersham), dried, and processed for autoradiography with Fuji medical x-ray film. Autoradiographs were digitized and analyzed by NIH Image 1.60 software.

Western immunoblot assay. Proteins were extracted using the above lysis buffer and quantified using a Micro BCA assay reagent kit (Pierce) as described previously ( $\mathrm{Li}$ et al., 1998). Aliquots (40 $\mu \mathrm{g}$ each) were loaded onto a $10 \%$ SDS-polyacrylamide gel, subjected to electrophoresis at $90 \mathrm{~V}$ for $1.5 \mathrm{hr}$, and transferred to Immobilon-P membranes. Membranes were incubated with monoclonal anti-AChE antibodies (NB04; Calbiochem, Cambridge, MA) overnight at $4^{\circ} \mathrm{C}$ and visualized using the Western-Light Chemiluminescent Detection System (Tropix, Inc., Bedford, MA). Films were digitized and analyzed using NIH Image 1.60 software. This technique assesses both area and intensity of the immunoreactive product.

Statistics. Statistical significance of differences between experimental treatments and controls were assessed using Student's $t$ test for unpaired data.

\section{RESULTS}

\section{IL-1 induces AChE mRNA expression in vivo}

In view of evidence of IL-1 involvement in induction of age- and stress-induced impairments of cholinergic systems (Murray and Lynch, 1998a,b), glutamate treatment-related induction of $\beta$ APP (Jolly-Tornetta et al., 1998) and AChE (Kaufer et al., 1998), and the induction of IL-1 production by sAPP (Barger and Harmon, 1997), we sought to determine whether experimentally induced increases in IL-1 levels might directly impact AChE expression in vivo. Implantation of slow-release IL- $1 \beta$-impregnated pellets into rat cerebrum produced significant elevations of AChE mRNA levels in contralateral cortex after $21 \mathrm{~d}$ relative to those in cortex of rats receiving pellets containing vehicle only or relative to levels in cortex of unoperated control rats $(p<0.01)$ (Fig. 1). AChE mRNA levels in cortex of rats receiving pellets containing

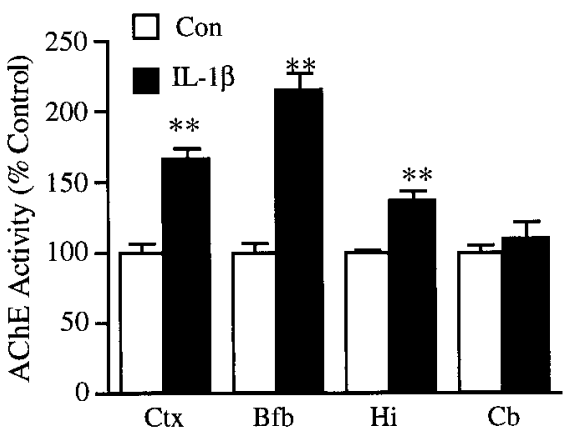

Figure 2. Induction of acetylcholinesterase activity in primary neuronal cultures after treatment with IL-1 $\beta$ (100 ng/ml for $24 \mathrm{hr})$. Cultures were derived from cerebral cortex $(C t x)$, basal forebrain $(B f b)$, hippocampus $(\mathrm{Hi})$, or cerebellum $(\mathrm{Cb})$. Values are expressed as mean $\pm \mathrm{SEM}$ for four replicates. $* * p<0.01$, significantly different from control.

vehicle only were not different from those in unoperated controls, suggesting that the elevation in AChE mRNA levels in rats with IL-1 pellets was not attributable to a nonspecific injury response but rather to exposure to increased levels of IL-1.

\section{IL-1 $\beta$ promotes AChE activity and expression in neurons in vitro}

IL- $1 \beta$ treatment increased AChE activity in primary neuronal cultures derived from three different forebrain regions (cerebral cortex, hippocampus, and basal forebrain) but not from cerebellum (Fig. 2). The greatest response was in neurons derived from basal forebrain. Stimulation of AChE activity by IL- $1 \beta$ appeared to be independent of cell proliferation because there was no observable difference in the numbers of AChE-positive cells (Fig. $3 E, F)$ in response to IL- $1 \beta$ treatment $[6.7 \pm 0.8$ (mean \pm SEM) vs $5.7 \pm 1.2 \%$ of total cortical cells and $8.5 \pm 1.4$ vs $8.0 \pm 1.4 \%$ total basal forebrain cells; treated vs control). Incubation with IL- $1 \beta$ did not alter BuChE or ChAT activity in these cultures (data not shown).

Treatment of PC12 cell cultures with IL-1 $\beta$ at concentrations of either $10 \mathrm{ng} / \mathrm{ml}$ or $100 \mathrm{ng} / \mathrm{ml}$ induced significant increases in AChE activity ( $p<0.006$ or better) (Fig. $4 A$ ). IL- $1 \beta$ treatment, in combination with NGF induction of neuronal differentiation in PC12 cell cultures, yielded even greater increases in AChE activity ( $>200 \%$ increase; $p<0.001$ ) (Fig. 5). IL- $1 \beta$-induced increases in AChE activity were evident after $12 \mathrm{hr}$ of incubation and were greater at $24 \mathrm{hr}$ (Fig. 4B). Preincubation of PC12 cell cultures with IL-1ra (500 ng/ml) blocked these effects (Fig. 4A). The morphology of PC1 2 cells was not altered by IL- $1 \beta$ treatment (Fig. $3 A-D$ ), and neither cell viability, as detected by MTT assay, nor numbers of PC12 cells were altered by IL- $1 \beta$ treatment $(1,10$, 100 , or $500 \mathrm{ng} / \mathrm{ml}$ for $24 \mathrm{hr}$; data not shown), suggesting that enhancement of AChE activity by IL- $1 \beta$ is independent of cell proliferation. These results suggest that these IL- $1 \beta$-induced increases represent actual increases in per cell activity of AChE in PC12 cells. Quantitative RT-PCR analysis showed that treatment of PC12 cell cultures with IL-1 $\beta$ for $24 \mathrm{hr}$ increased AChE mRNA expression by $40 \%(p<0.01)$ (Fig. 6). In addition, immunoblot analysis showed that this treatment increased AChE protein levels ( $p=0.034)$ (Fig. 7). These results were specific to both stimulus and response as two other cytokines [IL-6 (10 $\mathrm{ng} / \mathrm{ml})$ and TNF- $\alpha(10 \mathrm{ng} / \mathrm{ml})]$ did not alter AChE activity in PC12 cells (Fig. $4 A$ ), and IL-1 $\beta$ did not alter BuChE or ChAT activity in these cells (data not shown). 

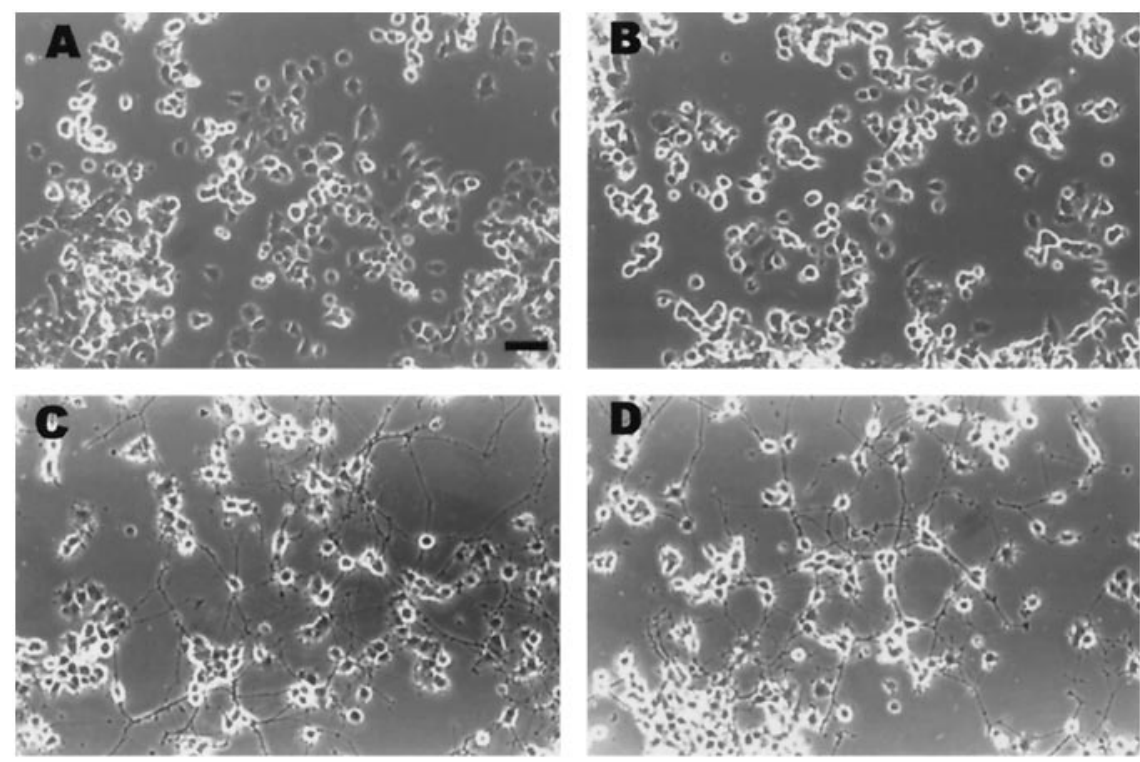

Figure 3. Phase-contrast photomicrographs of treated and untreated, differentiated and undifferentiated PC12 cell cultures $(A-D)$ and of primary cortical neuronal cultures $(E, F)$. $A$, Undifferentiated, untreated $\mathrm{PC} 12$ cell cultures. $B$, Undifferentiated PC1 2 cell cultures treated with IL-1 $\beta(100 \mathrm{ng} / \mathrm{ml}$ for $24 \mathrm{hr}$ ). $C$, Differentiated (NGF-induced), untreated PC12 cell cultures. D, Differentiated PC12 cell cultures treated with IL-1 $\beta(100 \mathrm{ng} / \mathrm{ml}$ for $24 \mathrm{hr})$. There are no discernible morphological difference between IL- $1 \beta$-treated and untreated PC1 2 cell cultures. $E, F$, Acetylcholinesterase histochemical reaction of primary cortical neuronal cultures in the absence $(E)$ or presence $(F)$ of IL-1 $\beta(100 \mathrm{ng} / \mathrm{ml}$ for $24 \mathrm{hr})$. There was no observable difference in the numbers of AChE-positive cells in response to IL- $1 \beta . A-D$ are the same magnification, and $E$ and $F$ are the same magnification. Scale bars, $60 \mu \mathrm{m}$.
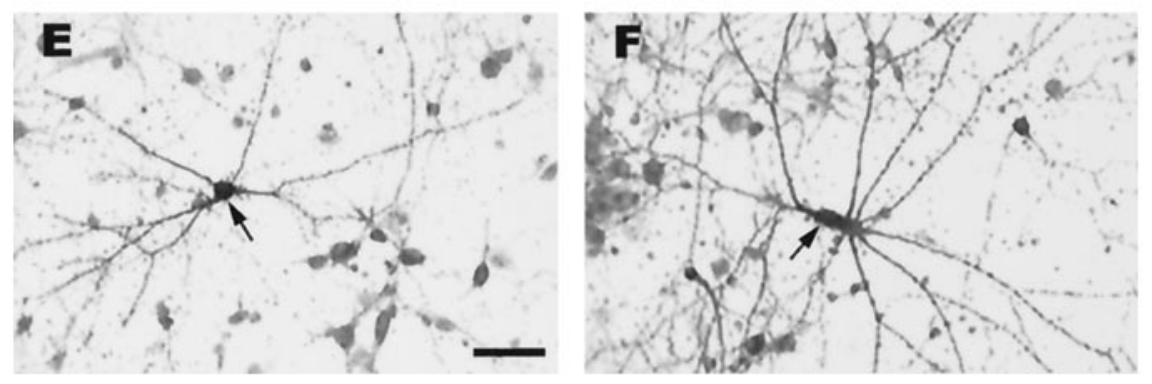

\section{Microglial activation by glutamate-treated neurons is mediated by secreted APP}

Glutamate exerts several forms of stress on neuronal cells. A large fraction of cortical neurons are susceptible to glutamate receptormediated excitotoxicity. In addition, high concentrations of glutamate exert a receptor-independent oxidative stress (Murphy et al., 1989) to which PC12 cells are vulnerable (Froissard et al., 1997). Both cellular $\beta$ APP (Fig. $8 A$ ) and media sAPP (Fig. $8 B$ ) levels increased significantly after treatment of PC12 cell cultures with glutamate $(p<0.05 ; n=3)$, in agreement with previous findings (Nitsch et al., 1997; Jolly-Tornetta et al., 1998). Similar increases in SAPP after glutamate treatment were also obtained using primary neuronal cultures (data not shown). Conditioned media from glutamate-treated PC12 cells induced synthesis ( $p=$ $0.008, n=4)$ (Fig. $8 C$ ) and release $(p<0.001 ; n=4)($ Fig. $8 D$ ) of IL-1 $\beta$ from N9 cells. This induction of N9 cell IL-1 $\beta$ expression by conditioned media from either glutamate-treated PC12 cells or glutamate-treated neuronal cultures was abolished by preabsorption of the conditioned media with anti-sAPP antibody (Fig. 8C), confirming that sAPP was responsible for the effects of such media on N9 cell expression of IL-1 $\beta$.

\section{IL-1 mediates the glial-neuronal interactions resulting in increased AChE expression}

Microglial cultures activated by incubation with media obtained from glutamate-treated PC12 cell cultures showed increases in cellular IL- $1 \beta$ mRNA levels $(p=0.008)$ (Fig. $8 C)$ and in media IL-1 $\beta$ levels $(p<0.001)$ (Fig. $8 D)$. Coculture of naive PC12 cell cultures with activated $\mathrm{N} 9$ cells resulted in a 1.6-fold increase in PC12 cell AChE activity $(p<0.01)$ (Fig. 9, Glut). Pretreatment of naive PC12 cells with IL-1ra before coculture with activated
N9 cell cultures abolished the inductive effects of N9 cell media on AChE activity (Fig. 9, Glut/IL-1ra) as did coculture of naive PC12 cells with N9 cells pretreated with either naive PC12 media (Fig. 9, Unt) or glutamate-treated PC12 media preabsorbed with anti-sAPP antibody (Fig. 9, Glut/anti-sAPP). Control experiments showed no increase in neuronal AChE activity or IL-1 mRNA expression in response to glutamate treatment alone (data not shown).

\section{DISCUSSION}

We demonstrate a cellular and molecular cascade of events in which secreted APP fragments derived from neurons stressed by glutamate treatment induce microglial activation with consequent inductive effects on neuronal AChE activity and mRNA levels. We further show that microglial overexpression of IL-1 is responsible for this increase in neuronal AChE activity and expression.

The neuronal-glial coculture system used in the present study proved to be an excellent model for the dissection of cellular and molecular mechanisms underlying glial regulation of neuronal functions. Using this model system, we demonstrated several novel glial-neuronal mechanisms. We showed for the first time microglial upregulation of neuronal AChE activity and gene expression. In addition, we identified the microglial factor responsible for this increase in activity and gene expression as IL- $1 \beta$. Moreover, we show the relevance of stress-induced release of sAPP (Nitsch et al., 1997; Jolly-Tornetta et al., 1998) to glial effects, mediated by IL-1, on the cholinergic system through neuronal expression of AChE.

Acetylcholinesterase hydrolyzes the neurotransmitter acetylcholine at postsynaptic membranes of central cholinergic syn- 

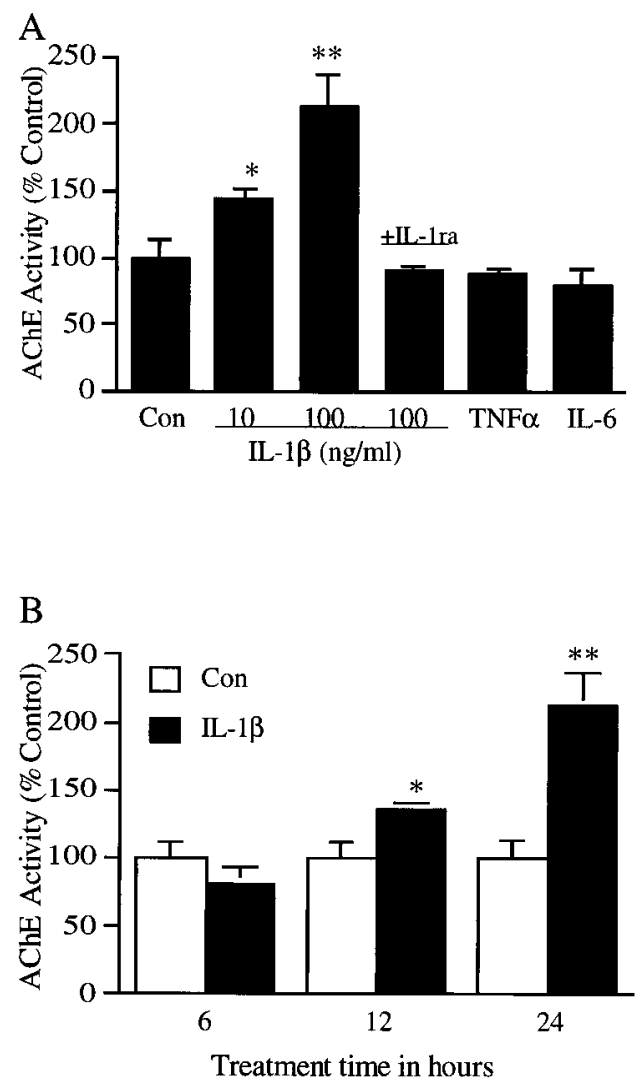

Figure 4. IL-1 $\beta$ induction of AChE activity in PC12 cell cultures. $A$, Dose-dependent induction of AChE activity after treatment with IL-1 $\beta$, IL- $1 \beta$ plus IL-1ra, TNF $\alpha$ alone, or IL- 6 alone. $B$, Time course of the IL-1 $\beta(100 \mathrm{ng} / \mathrm{ml})$ effect on undifferentiated PC12 cell cultures. Values expressed as mean \pm SEM for five replicates. ${ }^{*} p<0.05,{ }^{* *} p<0.01$, significantly different from corresponding control values.

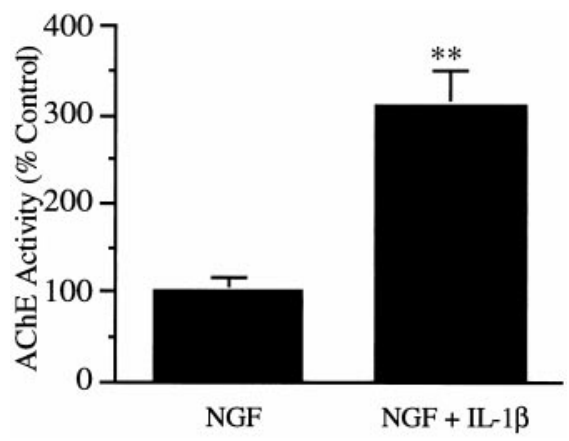

Figure 5. IL- $1 \beta$ induction of AChE activity in NGF-differentiated PC12 cell cultures. Values expressed as mean \pm SEM for eight replicates. ${ }^{* *} p<$ 0.001 , significantly different from corresponding control values.

apses, thus terminating synaptic transmission (Salpeter, 1967). Experimental animals subjected to a single "stress" session show elevated neocortical and hippocampal AChE activity for periods as long as $80 \mathrm{hr}$ (Kaufer et al., 1998). In Alzheimer's disease, there is an overall decline in average brain tissue levels of AChE (Atack et al., 1983), but this is accompanied by local overexpression of AChE in amyloid plaques (Ulrich et al., 1990; GomezRamos et al., 1992; Moran et al., 1993; Wright et al., 1993; Alvarez et al., 1997). Neuronal populations that show early involvement in Alzheimer's disease characteristically show high

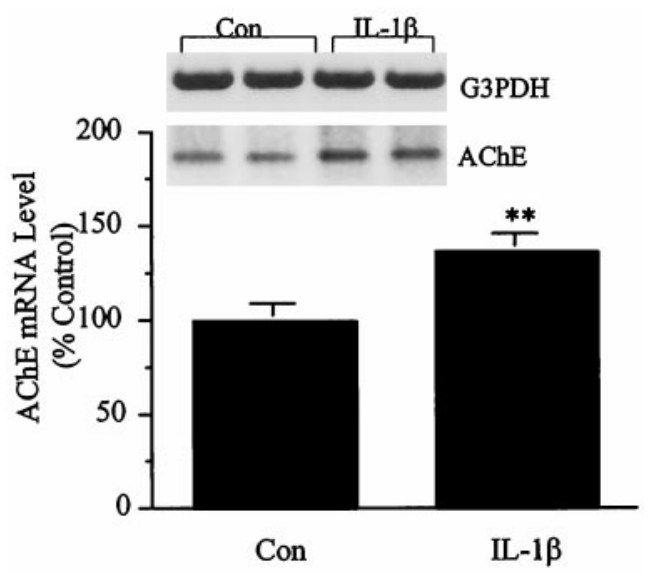

Figure 6. Induction of AChE mRNA expression in PC12 cell cultures after treatment with IL- $1 \beta(100 \mathrm{ng} / \mathrm{ml}$ for $24 \mathrm{hr})$. Values are expressed as mean \pm SEM for four replicates. ${ }^{* *} p<0.01$, significantly different from control.

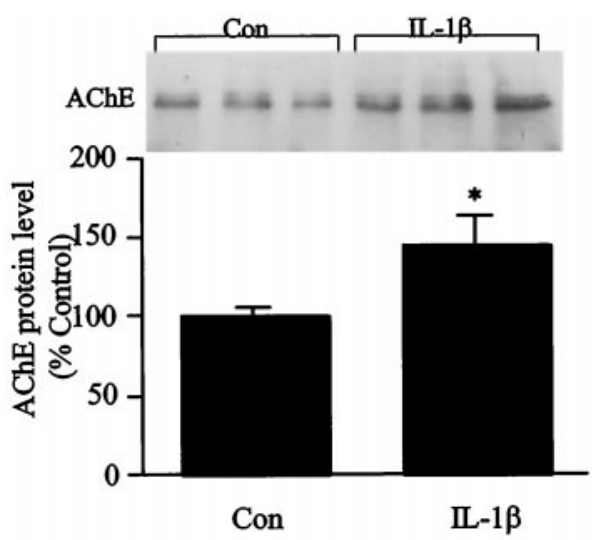

Figure 7. Induction of AChE protein expression in PC12 cell cultures after treatment with IL-1 $\beta$ (100 $\mathrm{ng} / \mathrm{ml}$ for $24 \mathrm{hr})$. Values are expressed as mean \pm SEM for six replicates. ${ }^{*} p=0.034$, significantly different from control.

levels of AChE expression (Smith and Cuello, 1984; Shen, 1994). In transgenic mice, overexpression of human AChE is accompanied by progressive cognitive deterioration (Beeri et al., 1995). It is conceivable that overexpression of $\mathrm{AChE}$ could also contribute to the amyloid pathology of Alzheimer's disease, because $\beta$-secretase activity, necessary for generating $\beta$-amyloid from $\beta A P P$, is under muscarinic receptor regulation (Muller et al., 1998), suggesting that declines in cholinergic neurotransmission would favor $\beta$-amyloid formation. Furthermore, direct physical interactions between $\mathrm{AChE}$ and $\beta$-amyloid promote formation of amyloid fibrils (Inestrosa et al., 1996).

There is now substantial evidence for an immunological ("inflammatory") component in the pathogenesis of Alzheimer's disease (Rogers and Griffin, 1997; Griffin et al., 1998). Activated microglia overexpressing IL-1 are prominent in cerebral cortex in Alzheimer's disease and are invariable components of the neuritic $\beta$-amyloid plaques (Griffin et al., 1995) shown to contain dystrophic neurites overexpressing AChE (Alvarez et al., 1997). IL-1 is a major proinflammatory cytokine that induces expression of several stress-associated molecules in neurons and astrocytes (Montz et al., 1991). These include $\beta$ APP (Goldgaber et al., 1989; Buxbaum et al., 1992; Forloni et al., 1992; Sheng et al., 1996; 

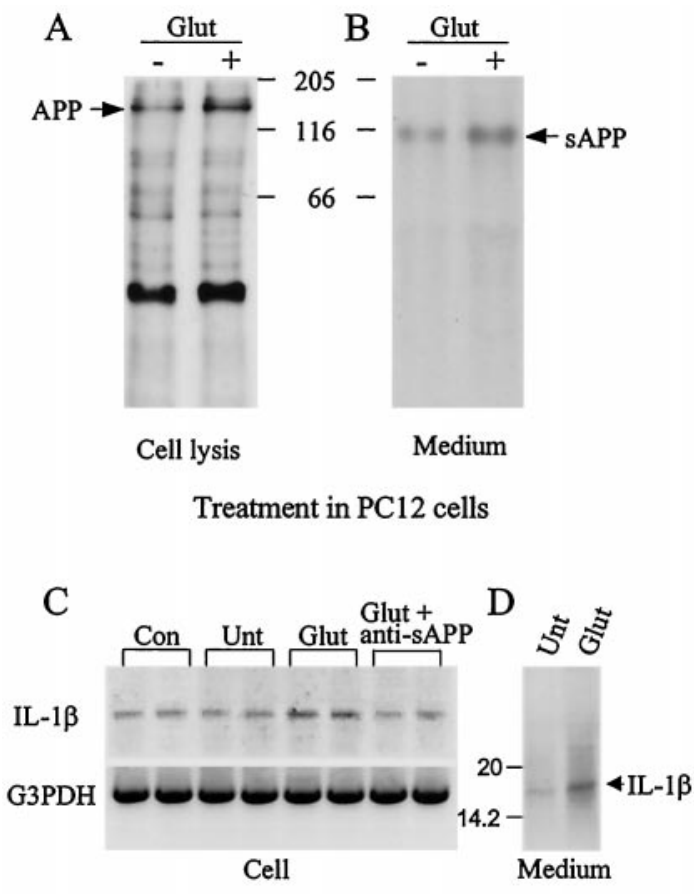

PC12 medium treatment of N9 cells

Figure 8. Illustration of increased $\beta$ APP synthesis in $(A)$ and release by (B) PC12 cell cultures, after $30 \mathrm{~min}$ of glutamate $(1 \mathrm{~mm})$ treatment. Illustration by RT-PCR of expression of IL- $1 \beta$ mRNA levels in N9 cell lysates $(C)$ from N9 cells that were not exposed to medium from PC12 cell (Con) or were treated with medium from untreated PC 12 cells (Unt), medium from glutamate-treated PC12 cells (Glut), or medium from glutamate-treated PC12 cells preabsorbed with anti-sAPP antibody $($ Glut + anti-sAPP). Illustration of IL- $1 \beta$ in N9 cell media by immunoprecipitation $(D)$ after treatment of $\mathrm{N} 9$ cell cultures with either medium from untreated PC 12 cells (Unt) or medium from glutamate-treated PC12 cells (Glut).

Rogers et al., 1999), which functions as an acute-phase protein and is upregulated in mouse brain in response to inflammatory processes (Brugg et al., 1995). In vivo, chronic neuroinflammation induced by lipopolysaccharides decreases cortical ChAT activity concomitant with activation of both astrocytes and microglia (Willard et al., 1999). We show here, in vitro and in vivo, that IL-1 mediates alterations in cholinergic properties. The specificity of these IL-1-induced increases in AChE expression were evident in the lack of accompanying alterations in ChAT activity [the latter in agreement with a previous report showing a lack of IL-1 $\beta$ effects on ChAT mRNA in sympathetic neuron cultures (Freidin and Kessler, 1991)] and in the ability of IL-1ra to block IL-1induced increases in $\mathrm{AChE}$ expression. The increases in $\mathrm{AChE}$ activity that we find in response to IL- $1 \beta$ were more pronounced in differentiated (neuronal) PC12 cell cultures than in undifferentiated PC12 cell cultures, suggesting that IL-1 receptor mechanisms are upregulated in concert with neuronal differentiation or with neuronal process growth.

Our findings may be interpreted in light of a "cytokine cycle" model of immunologically mediated neurodegeneration in Alzheimer's disease (Griffin et al., 1998). According to this model, IL-1-driven cytokine cascades initiate a self-propagating cycle of neuronal injury and consequent further microglial activation and further IL-1 overexpression. These immunological processes could produce IL-1- and sAPP-mediated effects on neuronal

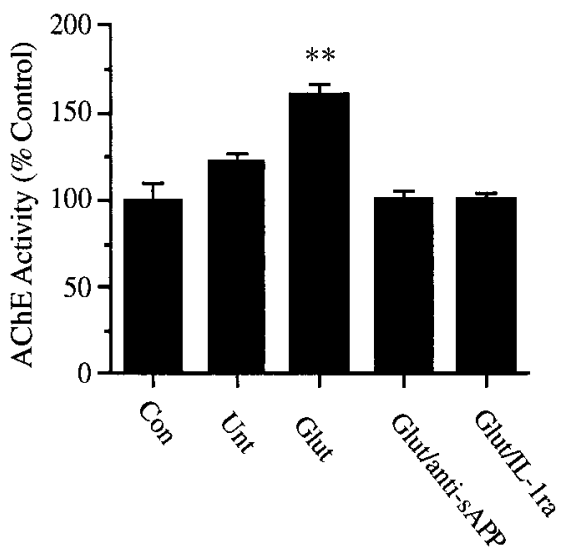

Figure 9. AChE activity in PC12 cells cocultured with N9 cells. Before coculture with naive PC12 cells, N9 cells either were not preincubated with PC12 cell medium (Con) or were preincubated with medium from naive PC12 cells $(U n t)$, media from glutamate-treated PC12 cells (Glut), or medium from glutamate-treated $\mathrm{PC} 12$ cells preabsorbed with antisAPP antibody (Glut/anti-sAPP). Before coculture with N9 cells that were preincubated with glutamate-treated medium, naive PC12 cells were pretreated with IL-1 receptor antagonist $(G l u t / I L-1 r a)$. Values are expressed as mean \pm SEM for at least five replicates. ${ }^{* *} p<0.01$, significantly different from control.

AChE levels or activity, as shown here, thus explaining the early and striking involvement of cholinergic systems in Alzheimer's disease. Our findings may also have implications for AChEmediated noncholinergic effects, such as those involving $\beta$ APP processing and aggregation of $\beta$-amyloid (Mori et al., 1995; Inestrosa et al., 1996). Thus, these findings may be useful in the development of more effective therapeutic strategies, because treatments aimed exclusively at enhancing cholinergic function in Alzheimer's disease would provide, at best, temporary and limited symptomatic respite from cholinergic dysfunction, whereas treatments aimed at slowing or halting the fundamental driving immunological processes would provide greater hope of slowing or arresting actual disease progression.

\section{REFERENCES}

Alvarez A, Opazo C, Alarcon R, Garrido J, Inestrosa NC (1997) Acetylcholinesterase promotes the aggregation of amyloid- $\beta$-peptide fragments by forming a complex with the growing fibrils. J Mol Biol 272:348-361.

Atack JR, Perry EK, Bonham JR, Perry RH, Tomlinson BE, Blessed G, Fairbairn A (1983) Molecular forms of acetylcholinesterase in senile dementia of Alzheimer type: selective loss of the intermediate (10S) form. Neurosci Lett 40:199-204.

Barger SW, Harmon AD (1997) Microglial activation by Alzheimer amyloid precursor protein and modulation by apolipoprotein E. Nature 388:878-881.

Barger SW, Mattson MP (1996) Induction of neuroprotective $\kappa$ Bdependent transcription by secreted forms of the Alzheimer's $\beta$-amyloid precursor. Mol Brain Res 40:116-126.

Bartus RT, Dean RL, Beer B, Lippa AS (1982) The cholinergic hypothesis of geriatric memory dysfunction. Science 217:408-417.

Beeri R, Andres C, Lev-Lehman E, Timberg R, Huberman T, Shani M, Soreq H (1995) Transgenic expression of human acetylcholinesterase induces progressive cognitive deterioration in mice. Curr Top Biol 5:1063-1071.

Brugg B, Dubreuil YL, Huber G, Wollman EE, Delhaye-Bouchaud N, Mariani J (1995) Inflammatory processes induce $\beta$-amyloid precursor protein changes in mouse brain. Proc Natl Acad Sci USA 92:3032-3035.

Buxbaum JD, Oishi M, Chen HI, Pinkas-Kramarski R, Jaffe EA, Gandy SE, Greengard P (1992) Cholinergic agonists and interleukin 1 regulate processing and secretion of the Alzheimer beta/A4 amyloid protein precursor. Proc Natl Acad Sci USA 89:10075-10078. 
Corridan SB, Mauel J, Donini SD, Quattrocchi E, Ricciardi-Castagnoli P (1993) Inducible nitric oxide synthase activity of cloned murine microglial cells. Glia 7:255-262.

Ellman GL, Courtney KD, Andres V, Featherstone RM (1961) A new and rapid calorimetric determination of acetylcholinesterase activity. Biochem Pharmacol 147:393-406.

Fonnum F (1975) A rapid radiochemical method for the determination of choline acetyltransferase. J Neurochem 24:407-409.

Forloni G, Demicheli F, Giorgi S, Bendotti C, Angeretti N (1992) Expression of amyloid precursor protein mRNAs in endothelial, neuronal and glial cells: modulation by interleukin-1. Brain Res Mol Brain Res 16:128-134.

Freidin M, Kessler JA (1991) Cytokine regulation of substance P expression in sympathetic neurons. Proc Natl Acad Sci USA 88:3200-3203.

Froissard P, Monrocq H, Duval D (1997) Role of glutathione metabolism in the glutamate-induced programmed cell death of neuronal-like PC12 cells. Eur J Pharmacol 326:93-99.

Goldgaber D, Harris HW, Hla T, Maciag T, Donnelly RJ, Jacobsen JS, Vitek MP, Gajdusek DC (1989) Interleukin 1 regulates synthesis of amyloid beta-protein precursor mRNA in human endothelial cells. Proc Natl Acad Sci USA 86:7606-7610.

Gomez-Ramos P, Mufson EJ, Moran MA (1992) Ultrastructural localization of acetylcholinesterase in neurofibrillary tangles, neuropil and senile plaques in aged and Alzheimer's brain. Brain Res 569:229-237.

Griffin WST, Stanley LC, Ling C, White L, MacLeod V, Perrot LJ, White CL III, Araoz C (1989) Brain interleukin 1 and S-100 immunoreactivity are elevated in Down syndrome and Alzheimer disease. Proc Natl Acad Sci USA 86:7611-7615.

Griffin WST, Sheng JG, Roberts GW, Mrak RE (1995) Interleukin-1 expression in different plaque types in Alzheimer's disease. J Neuropath Exp Neurol 54:276-281.

Griffin WST, Sheng JG, Royston MC, Gentleman SM, McKenzie JE, Graham DI, Roberts GW, Mrak RE (1998) Glial-neuronal interactions in Alzheimer's disease: the potential role of a cytokine cycle in disease progression. Brain Pathol 8:65-72.

Hall ZW, Kelly RB (1971) Enzymatic detachment of endplate acetylcholinesterase form muscle. Nat New Biol 232:62-63.

Inestrosa NC, Alvarez A, Perez CA, Moreno RD, Vicente M, Linker C, Casanueva OI, Soto C, Garrido J (1996) Acetylcholinesterase accelerates assembly of amyloid-b-peptides into Alzheimer's fibrils: possible role of the peripheral site of the enzyme. Neuron 16:881-891.

Jolly-Tornetta C, Gao Z, Lee VM-Y, Wolf BA (1998) Regulation of Amyloid precursor protein secretion by glutamate receptors in human Ntera 2 neurons (NT2N). J Biol Chem 273:14015-14021.

Kaufer D, Friedman A, Seidman S, Soreq H (1998) Acute stress facilitates long-lasting changes in cholinergic gene expression. Nature 393:373-377.

Layer PG, Willbold E (1995) Novel functions of cholinesterases in development, physiology and disease. Prog Histochem Cytochem 29:1-99.

Li Y, Wang J, Sheng JG, Liu L, Barger SW, Jones RA, Van Eldik LJ, Mrak RE, Griffin WST (1998) S100 $\beta$ increase levels of $\beta$-amyloid precursor protein and its encoding mRNA in rat neuronal cultures. J Neurochem 71:1421-1428.

Mesulam M-M (1986) Alzheimer plaques and cortical cholinergic innervation. Neuroscience 17:275-276.

Montz H, Koch KC, Zierz R, Gotze O (1991) The role of C5a in interleukin-6 production induced by lipopolysaccharide or interleukin-1. Immunology 74:373-379.

Moran MA, Mufson EJ, Gomez-Ramos P (1993) Colocalization of cholinesterases with $\beta$-amyloid protein in aged and Alzheimer's brain. Acta Neuropathol 85:362-369.

Mori F, Lai C, Fusi F, Giacobini E (1995) Cholinesterase inhibitors increase secretion of APPs in rat brain cortex. NeuroReport 6:633-636.

Muller D, Wiegmann H, Langer U, Motzen-Lenz S, Nitsch RM (1998) $\mathrm{Lu} 25-109$, a combined $\mathrm{m} 1$ agonist and $\mathrm{m} 2$ antagonist, modulates regulated processing of the amyloid precursor protein of Alzheimer's disease. J Neural Transm 105:1029-1043.

Murphy TH, Miyamoto M, Sastre A, Schnaar RL, Coyle JT (1989) Glutamate toxicity in a neuronal cell line involves inhibition of cystine transport leading to oxidative stress. Neuron 2:1547-1558.
Murray CA, Lynch MA (1998a) Evidence that increased hippocampal expression of the cytokine interleukin-1 beta is a common trigger for age- and stress-induced impairments in long-term potentiation. J Neurosci 18:2974-2981.

Murray CA, Lynch MA (1998b) Dietary supplementation with vitamin $\mathrm{E}$ reverses the age-related deficit in long term potentiation in dentate gyrus. J Biol Chem 273:12161-12168.

Nitsch RM, Deng A, Wurtman RJ, Growdon JH (1997) Metabotropic glutamate receptor subtype mGluR $1 \alpha$ stimulates the secretion of the amyloid beta-protein precursor ectodomain. J Neurochem 69:704-712.

Paciotti GF, Tamarkin L (1988) Interleukin-2 differentially affects the proliferation of a hormone-dependent and a hormone-independent human breast cancer cell line in vitro and in vivo. Anticancer Res 8:1233-1239.

Rogers J, Griffin WST (1997) Inflammatory mechanisms of Alzheimer's disease. In: Neurodegeneration: inflammatory mechanisms and management (Wood PL, ed), pp 177-193. Totowa, NJ: Humana.

Rogers JT, Leiter LM, McPhee J, Cahill CM, Zhan SS, Potter H, Nilsson LN (1999) Translation of the Alzheimer amyloid precursor protein mRNA is up-regulated by interleukin-1 through $5^{\prime}$-untranslated region sequences. J Biol Chem 274:6421-6431.

Salpeter M (1967) Electron microscope radioautography as a quantitative tool in enzyme cytochemistry. I. The distribution of acetylcholinesterase at motor endplates of a vertebrate twitch muscle. J Cell Biol 32:379-389.

Sberna G, Saez-Valero J, Li Q-X, Czech C, Beyreuther K, Masters CL, McLean CA, Small DH (1998) Acetylcholinesterase is increased in the brains of transgenic mice expressing the C-terminal fragment (CT100) of the $\beta$-amyloid protein precursor of Alzheimer's disease. J Neurochem 71:723-731.

Schneider H, Pitossi F, Balschun D, Wagner A, del Rey A, Besedovsky HO (1998) A neuromodulatory role of interleukin-1beta in the hippocampus. Proc Natl Acad Sci USA 95:7778-7783.

Shen ZX (1994) Acetylcholinesterase provides deeper insights into Alzheimer's disease. Med Hypoth 43:21-30.

Sheng JG, Mrak RE, Rovnaghi CR, Kozlowska E, Van Eldik LJ, Griffin WST (1996) Human brain S100 $\alpha$ and S100 $\beta$ mRNA expression increases with age: Pathogenic implications for Alzheimer's disease. Neurobiol Aging 17:359-363.

Smith AD, Cuello AC (1984) Alzheimer's disease and acetylcholinesterase-containing neurons. Lancet 1:513.

Sternfeld M, Ming G-L, Song H-J, Sela K, Timberg R, Poo M-M, Soreq H (1998) Acetylcholinesterase enhances neurite growth and synapse development through alternative contributions of its hydrolytic capacity, core protein, and variable C termini. J Neurosci 18:1240-1249.

Tago H, Kimura H, Maeda T (1986) Visualization of detailed acetylcholinesterase fiber and neuron staining in rat brain by a sensitive histochemical procedure. J Histochem Cytochem 34:1431-1438.

Ulrich J, Meier-Ruge W, Probst A, Meier E, Ipsen S (1990) Senile plaques: staining for acetylcholinesterase and A4 protein: a comparative study in the hippocampus and entorhinal cortex. Acta Neuropathol 80:624-628.

Whitehouse PJ, Price DL, Clark AW, Coyle JT, DeLong MR (1981) Alzheimer disease: evidence for selective loss of cholinergic neurons in the nucleus basalis. Ann Neurol 10:122-126.

Willard LB, Hauss-Wegrzyniak B, Wenk GL (1999) Pathological and biochemical consequences of acute and chronic neuroinflammation within the basal forebrain cholinergic system of rats. Neuroscience 88:193-200.

Winkler J, Suhr ST, Gage FH, Thal LJ, Fisher LJ (1995) Essential role of acetylcholine in spatial memory. Nature 375:484-487.

Wright CI, Geula C, Mesulam M-M (1993) Protease inhibitors and indoleamines selectively inhibit cholinesterases in the histopathologic structures of Alzheimer disease. Proc Natl Acad Sci USA 90:683-686.

Younkin SG, Goodridge B, Katz J, Lockett G, Nafziger D, Usiak MF, Younkin LH (1986) Molecular forms of acetylcholinesterase in Alzheimer's disease. Fed Proc 45:2982-2988. 